\title{
B1 Clonagem, expressão e purificação de proteína imunogênica de Acinetobacter baumannii
}

Anna Erika Vieira de Araujo ${ }^{1}$, Luis Vidal Conde', Lucas Almeida Machado $^{1}$, José Procópio Moreno Senna ${ }^{1}$

1 Vice-Diretoria de Desenvolvimento Tecnológico, Programa de Biofármacos Laboratório de Tecnologia Recombinante BioManguinhos, Fundação Oswaldo Cruz, Rio de Janeiro, Brasil

Introdução: Acinetobacter baumannii é um importante patógeno oportunista no mundo inteiro, com alta incidência em unidades de tratamento intensivo, acometendo principalmente pacientes imunossuprimidos. Recentemente foi relatado que, no Brasil, de 15 a $20 \%$ dos isolados desta bactéria apresenta resistência aos antibióticos $\beta$-lactâmicos, incluindo os carbapenens, o que dificulta o tratamento e abre espaço para a busca de terapias alternativas, como as imunoterapias. Em trabalhos anteriores, foi identificada uma proteína com potencial imunogênico denominada OmpA.

Objetivos: Clonagem, expressão e purificação da proteína OmpA de Acinetobacter baumannii.

Metodologia: Para amplificação do gene bacteriano por PCR, foram utilizados primers sintetizados pela empresa IDT $^{\odot}$, a partir da sequência tirada do banco de dados do NCBI e montada com o auxílio do programa DNA Vector. O gene da proteína OmpA foi amplificado e clonado no vetor pET28a, com as enzimas de restrição Nhel e Hindll, em Escherichia coli TOP10. A expressão do gene foi feita em Escherichia coli BL-21 (DE3) e a purificação foi realizada a partir da solubilização dos corpos de inclusão com uréia, submetendo-se em seguida à cromatografia por afinidade em coluna de níquel. O refolding da proteína foi realizado através de diálise em PBS.

Resultados: Da amplificação e clonagem foi possível obter um gene de $1005 \mathrm{bp}$, correspondente à sequência da proteína OmpA. Na indução de expressão proteica com IPTG, verificou-se a superexpressão do gene de interesse, na forma de proteína com peso molecular de aproximadamente $45 \mathrm{kDa}$, sendo que a maior parte desta foi expressa na forma insolúvel de corpos de inclusão. Após a purificação, diálise e refolding, foi possível obter uma fração homogênea da proteína de interesse na faixa de peso correspondente a $45 \mathrm{kDa}$.

Conclusão: Este estudo mostrou que é possível obter a proteína imunogênica OmpA de Acinetobacter baumannii em sistema de expressão de Escherichia coli, e purificá-la através de cromatografia 
por afinidade, obtendo uma fração proteica homogênea com banda majoritária na faixa de $45 \mathrm{kDa}$. Esses resultados são essenciais para avaliar o potencial da OmpA como alvo imunoterápico, podendo ser futuramente utilizada em vacinas ou anticorpos monoclonais.

Palavras-Chave: Acinobacter baumanni, OmpA, Proteína, Imunoterapias 